\title{
The impact of sirolimus therapy on lesion size, clinical symptoms, and quality of life of patients with lymphatic anomalies
}

\author{
Michio Ozeki ${ }^{1,2^{*}}$, Akifumi Nozawa', Shiho Yasue ${ }^{1}$, Saori Endo ${ }^{1}$, Ryuta Asada ${ }^{2,3}$, Hiroya Hashimoto ${ }^{3}$ and \\ Toshiyuki Fukao'
}

\begin{abstract}
Background: Lymphatic anomalies (LAs) include several disorders in which abnormal lymphatic tissue invades the neck, chest, and various organs. Progressive cases may result in lethal outcomes and have proven difficult to treat. Sirolimus is showing promising results in the management of vascular anomalies. We examined the efficacy and safety of sirolimus treatment in patients with progressive LAs.

Methods: All patients with LAs treated with sirolimus from May 2015 to September 2018 were included. They received oral sirolimus once a day and the dose was adjusted so that the trough concentration remained within $5-15 \mathrm{ng} / \mathrm{mL}$. We prospectively reviewed the response to drugs (the response rate of radiological volumetric change of the target lesion), severity scores, reported quality of life (QOL), and adverse effects at 6 months after administration.

Results: Twenty patients (five with cystic lymphatic malformation (LM), three with kaposiform lymphangiomatosis, three with generalized lymphatic anomaly, six with Gorham-Stout disease, and three with central conducting lymphatic anomaly) were treated with sirolimus at our institution. Fifty percent of patients (10/20) demonstrated a partial response by a radiological examination and a significant improvement in disease severity and QOL scores ( $P=0.0020$ and $P=0.0117$, respectively). Ten patients who had no reduction in lesion size (stable disease group) showed no significant improvement in disease severity and QOL scores. Eighty percent of patients (16/20) had side effects, such as stomatitis, infection, and hyperlipidemia.
\end{abstract}

Conclusions: Sirolimus impacts the reduction of the lymphatic tissue volume of LMs and could lead to improvement in clinical symptoms and QOL.

Trial registration: UMIN Clinical Trials Registry, UMIN000016580. Registered 19 February 2015,

Keywords: Vascular malformations, Lymphatic malformation, Generalized lymphatic anomaly, Gorham-stout disease, Mammalian target of rapamycin

\section{Background}

Lymphatic anomalies (LAs) are rare diseases that are caused by abnormalities of the lymphatic system and include cystic lymphatic malformation (LM), generalized lymphatic anomaly (GLA), Gorham-Stout disease (GSD),

\footnotetext{
*Correspondence: michioo@gifu-u.ac.jp

'Department of Pediatrics, Graduate School of Medicine, Gifu University, 1-1, Yanagido, Gifu 501-1194, Japan

${ }^{2}$ Innovative and Clinical Research Promotion Center, Graduate School of Medicine, Gifu University, 1-1, Yanagido, Gifu 501-1194, Japan

Full list of author information is available at the end of the article
}

and central conducting lymphatic anomaly (CCLA) [1]. These are classified as LMs, according to the International Society for the Study of Vascular Anomalies (ISSVA) classification [2]. Cystic LMs present at birth in up to $60 \%$ of LA cases and the pathology of cystic LMs is quite variable, ranging from a focal area with minimal swelling to large areas of diffusely infiltrating aberrant lymphatic channels [3]. Depending on their location and extent of the lesion, LMs can affect vital physiological functions. Surgical resection and sclerotherapy are usually effective in treating and resolving macrocystic LMs. However, microcystic

(c) The Author(s). 2019 Open Access This article is distributed under the terms of the Creative Commons Attribution 4.0 International License (http://creativecommons.org/licenses/by/4.0/), which permits unrestricted use, distribution, and 
LMs are more infiltrative and difficult to treat. Interferon, corticosteroids, and propranolol have been used in the treatment of inoperable LMs, although their effects are limited and they are not indicated for this disease [3]. GLA is a rare and often fatal congenital lymphatic disorder that also commonly affects bone; it occurs predominantly in childhood or early adulthood. Kaposiform lymphangiomatosis (KLA) is a novel subtype of GLA with foci of spindle endothelial cells amid a background of malformed lymphatic channels [1, 4]. GSD is also characterized by lymphatic malformation, affecting a single or multiple bones and adjacent soft tissues; the osteolysis is progressive and invades the bone cortex [4]. The progression of GSD often includes visceral progression with thoracic and abdominal involvement, leading to effusions and ascites [4]. CCLAs are channel-type lymphatic malformations of named trunks. Anatomic changes like stenosis or closure of the large draining lymphatics like the thoracic duct as well as dysfunction lead to a reflux into the conducting channels with leakage into organs and skin [1]. A survey of previously published studies [4] of these diseases in Japan showed that the mortality rate was 20\% (17/85) and all of the deceased had thoracic lesions. Management of LAs is challenging, with frequent poor responses to medical therapy and a poor prognosis [1].

The mammalian target of rapamycin (mTOR) activates protein synthesis, resulting in numerous cellular processes including cell proliferation and increased angiogenesis, thus playing a key role in the pathogenesis of various vascular anomalies [5]. The mTOR inhibitor sirolimus has been identified recently as a promising treatment for LAs. Hammill et al. reported on four patients with diffuse microcystic LM who displayed good clinical response to sirolimus treatment with mild and reversible side effects [5]. Adams et al. showed a high response rate to sirolimus treatment in LA patients [6]. Some studies have investigated the mechanisms by which sirolimus acts on lymphatic endothelial cells and LM lesions in these patients [7]. Sirolimus has also been shown to inhibit lymphangiogenesis [7]. In preclinical models, rapamycin prevents or inhibits lymphangiogenesis in zebrafish [8] and in mouse skin flaps, kidney allograft injury, and tumor metastasis $[9,10]$. Rapamycin also suppresses growth of lymphatic endothelial cells in vitro [11]. It is thought to act on lymphatic tissues within lesions to regulate the production and leakage of lymph by decreasing lymphatic endothelial cell activity. Thus, we conducted this study to verify whether treatment with sirolimus will reduce the volume of lesions in lymphatic tissues and improve clinical symptoms in patients with LAs.

Herein we present our experience with 20 patients treated with sirolimus and discuss medical actions taken in the treatment of lymphatic lesions and patient outcomes.

\section{Methods \\ Study objectives}

The primary objective of the study was to assess the radiographic response rate (response rate of radiological volumetric change of the target lesion) to sirolimus treatment at 6 months. Secondary study objectives were as follows:

To assess the radiological response rate at 3 months

To assess improvement in the clinical severity score and the quality of life (QOL) score at 6 months

To assess the association of the radiological response with improvement in the clinical severity and QOL scores

To assess the safety (adverse events and side effects) of sirolimus treatment in patients with LAs

\section{Study outline and enrollment}

This was a prospective trial at Gifu University Hospital in Japan. Informed consent was obtained from patients, parents, or legal guardians (when the subject's age was less than 20 years at consent). Inclusion criteria were as follows: definitively diagnosed with cystic LM (head, neck, thoracic, peritoneal cavity, or retroperitoneum), GLA, GSD, or CCLA, excluding other lymphatic diseases (primary lymphedema and others); having at least one target lesion (e.g., cystic LM or lymphedema) that was measurable using magnetic resonance imaging (MRI); and having severe disorders and symptoms that required systemic therapy because of the target disease (bleeding, chronic pain, recurrent cellulitis, ulceration, visceral and/or bone involvement, as well as potential effects on organ function, including the eye, airway, and ear). Criteria for patients with LAs were defined as follows: cystic LM involved single, or multiple cystic LM lesions; KLA also involved multiple lymphatic lesions with spindle cell foci confirmed by pathological examination; GSD involved cortical bone loss and/or progressive bone resorption; GLA involved diffuse multiple lymphatic lesions in which spindle cell foci were not confirmed by pathological examination and there was an absence of progressive osteolysis; and CCLA had evidence of central conducting lymphatic channel abnormalities by radiological examination. Exclusion criteria were as follows: an active infection that requires systemic treatment; uncontrolled diabetes, hypertension, hyperlipidemia, or a chronic liver or kidney disease; a history of an allergic reaction to sirolimus; an immunodeficiency condition such as a human immunodeficiency viral infection or primary immunodeficiency disease; having undergone surgery (resection, sclerotherapy, or endovascular treatment), drugs (steroids, interferon, Chinese herbs, or chemotherapeutic agents) for the target lesion within at least 8 weeks prior to the date of obtaining consent for participation in this trial, or not being able to deny the possibility of remaining effects caused by surgery; pregnant, breast-feeding, or may be pregnant, or without consent to 
contraception during the clinical trial period; or judged by the principal investigator/sub-investigator to be ineligible to participate in this clinical trial for other reasons.

\section{Treatment and evaluation}

Patients with a body surface area (BSA) $\geq 1.0 \mathrm{~m}^{2}$ were administered $2 \mathrm{mg}$ (2 tablets) once a day, while those with a BSA of $<1.0 \mathrm{~m}^{2}$ were administered $1 \mathrm{mg}$ ( 1 tablet) once a day. Patients unable to swallow whole tablets took crushed sirolimus tablets at a dose of $1.6 \mathrm{mg} / \mathrm{m}^{2}$ once per day. The dose was adjusted so that the nadir concentration remained within $5-15 \mathrm{ng} / \mathrm{ml}$. All patients were treated with sulfamethoxazole/trimethoprim for prevention of Pneumocystis pneumonia. Discontinuation criteria were as follows: hematotoxicity over grade 3 according to the Common Terminology Criteria for Adverse Events (CTCAE) V4.0, adverse event other than hematotoxicity (except hyperlipidemia) over grade 4 according to CTCAE V4.0, or other equivalent reasons as determined by the principal physician.

The primary endpoint was response rate, defined as the proportion of patients who achieved a complete response or partial response as determined by radiological examination at 6 months after initiating treatment with the trial drug. The area dimensions of lymphatic tissues or cysts demonstrated using MRI with T2 fat-saturated sequences were measured using the Digital Imaging and Communications in Medicine (DICOM) viewer (OsiriX॰ v.9.0; Pixmeo. Bernex, Switzerland). Quantitative analysis was automatically performed to measure the area dimensions of the lesion using the region of interest (ROI) tool. If ROIs could not be calculated because of the intricate shapes of the lesions, measurement was performed using a manual computing tool (closed polygon ROI). Other pathological lesions, namely inflammatory, bleeding, and hematomas, were removed. The volume of the target lesion was calculated by multiplying these ROI areas by the slice width. If the affected area was diffuse or extensive, the measuring range was based on the normal organ position and landmarks (e.g., location of the spine). The evaluation criteria were defined as follows: complete response (CR), disappearance of all target lesions; partial response (PR), at least a $20 \%$ decrease in volume of the target lesion; progressive disease (PD), a $20 \%$ or greater increase in volume of the target lesion; and stable disease (SD), insufficient shrinkage to qualify as a partial response and insufficient growth to qualify as PD. Secondary endpoints were the response rate at 3 months, improvement in clinical symptoms caused by LM lesions, QOL scores at pretreatment and 6 months, and side effects. These were measured using PedsQL ${ }^{\mathrm{mi}} 4.0$ Generic Core Scales $(<25$ years old) [12], Functional Assessment of Cancer Therapy-General (FACT-G) (> 25 years old) [13], and CTCAE V4.0, respectively. The QOL scale was adjusted based on the QOL scale for each age. Regarding clinical symptoms, the optimal measure of disease severity in patients with vascular anomalies has not been established because LMs cause various symptoms and affect several organs. Therefore, this study used the severity measurement score for vascular anomalies to assess the degree of impairment of affected organs (Table 1). This score has been adopted from other severity scales that have been validated or are conventional objective measurements (ex. CTCAE, World Health Organization bleeding scale [14], and modified Rankin Scale [15]).

\section{Data analysis}

Descriptive statistical methods and the Wilcoxon signed rank test for comparison between pretreatment and 6 months were used in the statistical analyses. Statistical analysis was performed using GraphPad Prism version 7. A value of $P<0.05$ was considered statistically significant.

\section{Results}

\section{Patient characteristics}

We reviewed 20 patients with LMs (five with cystic LM, three with KLA, three with GLA, six with GSD, and three with CCLA) who were treated with sirolimus at our institution. Patient characteristics and treatment are summarized in Table 2. Mean patient age was 16.0 years (range: 2 weeks- 55 years). Five patients with LM had giant craniocervical lesions, and treatment of these lesions with surgery and sclerotherapy was not effective. They suffered from recurrence of respiratory distress, mucosal bleeding, and chronic infections. Three patients with KLA had medullary bone osteolysis, thoracic and mediastinal masses, and coagulation disorders, causing respiratory distress, chylothorax, and gastrointestinal hemorrhaging. They were pathologically diagnosed with KLA. It was difficult to control these symptoms with conventional treatment. Three patients with GLA also had thoracic and abdominal lesions and suffered from ascites, lymphorrhea, and cellulitis. Patients with GSD had osteolytic lesions in the thigh, lower limbs, skull base, and mandible. These lesions were progressive and destructive, and patients suffered from pathological fractures, pain, and neurological disorders. An infiltrative soft tissue abnormality adjacent to the area of osseous involvement was identified. Two patients with CCLA had an abnormality in the central conducting lymphatic channels, thoracic and mediastinal lesions, and leakage of lymph fluid. These symptoms were intractable and uncontrollable by conventional therapies. All patients had at least one target lesion (e.g., a cystic LM or lymphedema) that was measurable using MRI, and they were examined at 3 and 6 months (Fig. 1).

\section{Treatments, efficacy, and safety}

The mean duration of sirolimus treatment was 12.5 months (range: 6-30 months). The mean trough concentration of 


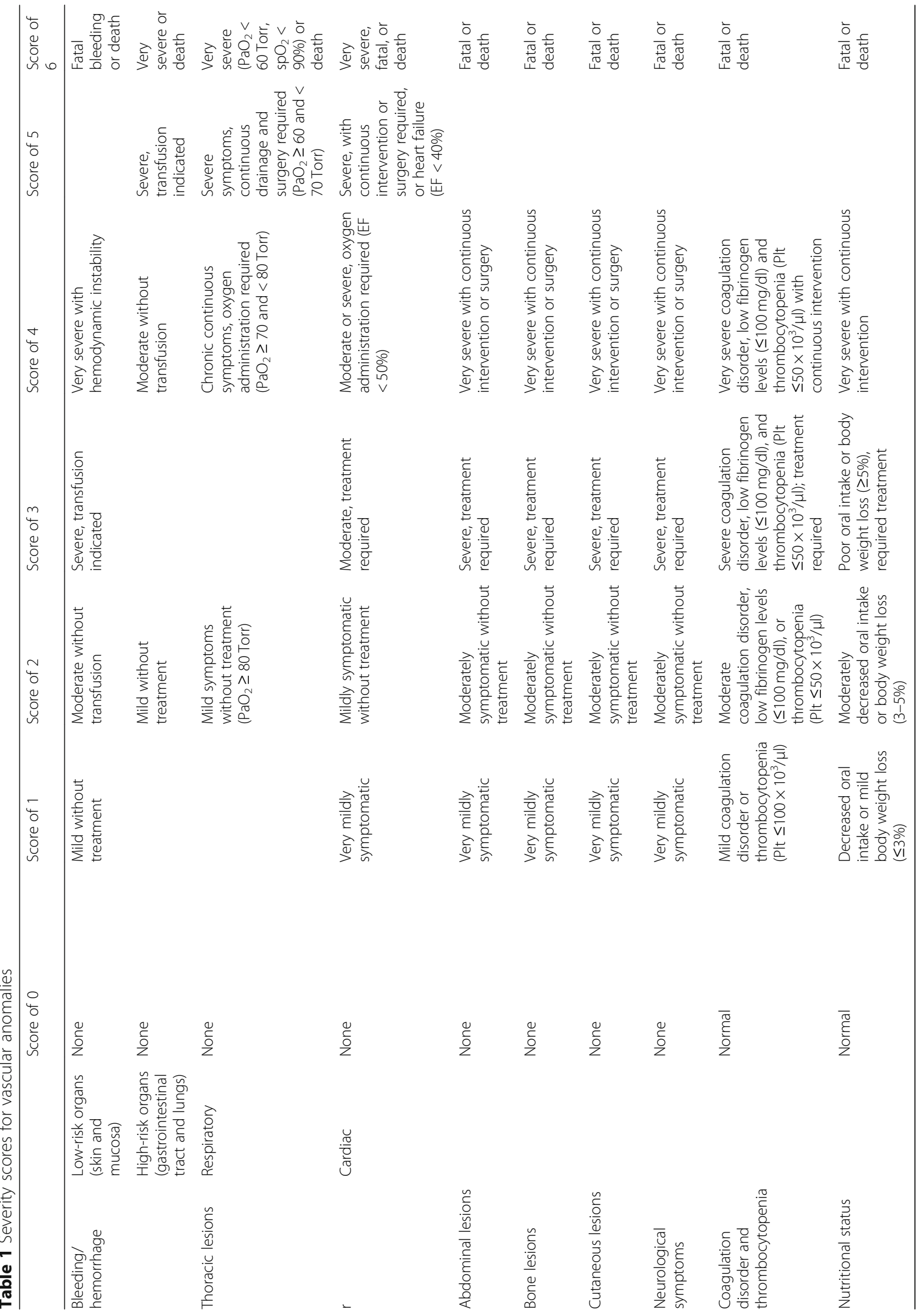




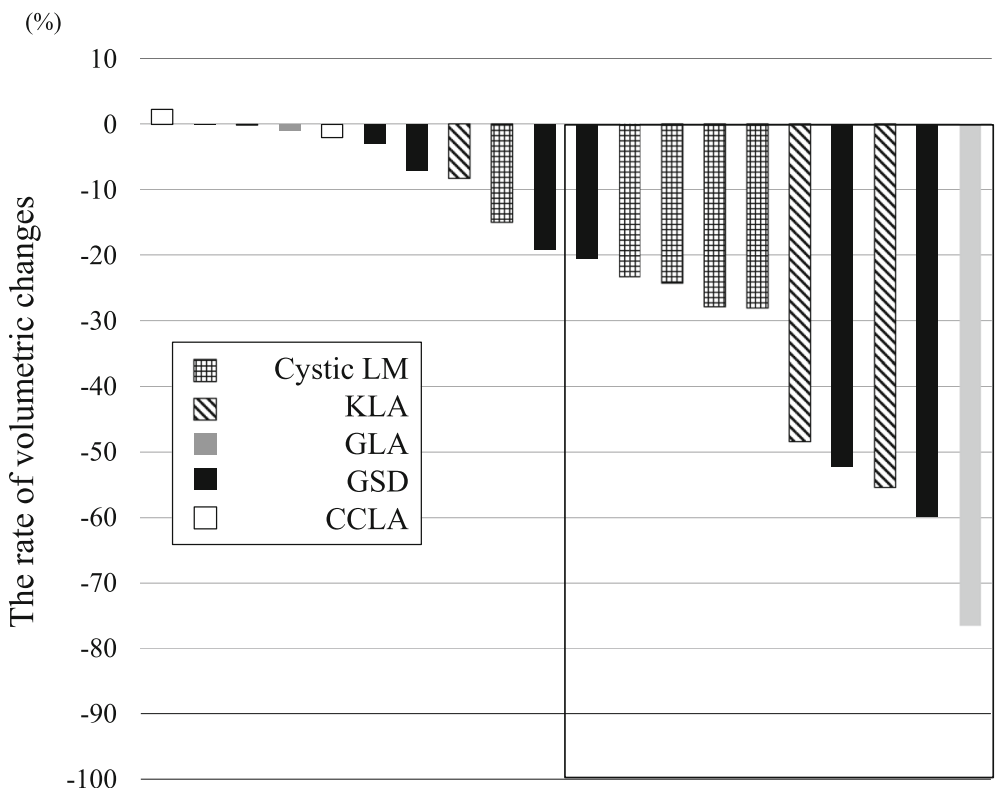

Fig. 1 Volumetric change shown using radiological examination in patients 6 months following the start of sirolimus treatment

sirolimus was $6.8 \mathrm{ng} / \mathrm{ml}$. Although the trough level of sirolimus in $70.0 \%(14 / 20)$ of patients at 2 weeks after administration was less than $5 \mathrm{ng} / \mathrm{ml}$, the levels after loading increased to target trough levels. All patients were able to continue treatment for over 6 months without any discontinuations.

Case number 2: a 2-week-old girl had a giant cystic LM lesion in her right neck, axilla, trunk, and abdominal cavity from the fetal period. The right axilla lesion showed hemorrhagic cysts and contained venous components. She needed a blood transfusion because of her anemia. Written informed consent was obtained from the patient's parents for treatment and photographs and she was treated with oral sirolimus. One week later, her anemia and the color tones of her lesions improved without any other treatments, such that she did not require another blood transfusion. All LM lesions gradually decreased and the patient had no treatment-related side effects. The rate of radiological volumetric change in the lesion at 6 months was $-24.2 \%$ (Fig. 2).

Case number 7: an 8-year-old boy with KLA suffered from severe scoliosis, pain, thrombocytopenia, and coagulopathy. The radiological examination showed diffuse osteolytic lesions of the spine, a mediastinal mass, and thickening of bronchovascular bundles and interlobular septa. A biopsy specimen from the lesion showed dilated malformed lymphatic channels lined with a single layer of endothelial cells and foci of abnormal spindle lymphatic endothelial cells. Written informed consent was obtained from the patient's parents for treatment and photographs and he was treated with sirolimus; however, the radiological response showed that he had SD $(-8.3 \%$ volumetric reduction in the lesion), and his symptoms, including scoliosis and coagulopathy, did not improve at 6 months after the start of treatment (Fig. 3). The patient did not have any severe side effects.

Fifty percent $(10 / 20)$ of patients had a PR by radiological examination at 6 months. At 3 months, 35.0\% (7/ 20) already showed a PR and the volume of their lesions was reduced over time. No patient achieved a CR. Lesion size did not increase by $20 \%$ or more in any patient; however, symptoms of one GSD patient (number 15) and one CCLA patient (number 20) worsened, and both died because of disease progression. The entire patient cohort had a significant improvement in the total severity score of their disease and in the QOL score $(p=$ 0.0029 and $p=0.0129$, respectively) (Table 3 ). Both physical and psychological QOL scores also improved. The PR group of patients showed a significant improvement in the total severity score of their disease and QOL score $(p=0.0020$ and $p=0.0117$, respectively). However, 10 patients who had SD and did not have a reduction in the size of their lesions showed no improvement in the total severity score or QOL score. Four SD patients (numbers $5,10,18$, and 19) did not have any reduction in the size of their lesions, but total severity scores and QOL scores improved. Some severity scores of particular organs in patients with symptoms at pretreatment showed a tendency of improvement (the mean change severity score after sirolimus treatment: bleeding of low-risk organ $(n=8) ;-1.125$, respiratory $(n=9) ;-1.0$, abdominal 
Table 2 Characteristics of patients treated with sirolimus

\begin{tabular}{|c|c|c|c|c|c|c|c|c|c|}
\hline $\mathrm{N}$ & $\begin{array}{l}\text { Age at } \\
\text { start/ } \\
\text { sex }\end{array}$ & Diagnosis & $\begin{array}{l}\text { Location of target } \\
\text { lesions }\end{array}$ & Complications & $\begin{array}{l}\text { Previous } \\
\text { treatment }\end{array}$ & $\begin{array}{l}\text { Dosing } \\
\text { period } \\
\text { (months) }\end{array}$ & $\begin{array}{l}\text { Range (mean) } \\
\text { of trough } \\
\text { concentrations } \\
(\mathrm{ng} / \mathrm{mL})\end{array}$ & $\begin{array}{l}\text { Evaluation } \\
\text { of } \\
\text { radiological } \\
\text { volumetric } \\
\text { change } \\
\text { (change } \\
\text { rate, \%) }\end{array}$ & $\begin{array}{l}\text { Adverse effects } \\
\text { associated with } \\
\text { sirolimus } \\
\text { (CTCAE Grade) }\end{array}$ \\
\hline 1 & $\begin{array}{l}1 \text { year/ } \\
M\end{array}$ & Cystic LM & Neck and tongue & $\begin{array}{l}\text { Disturbance of } \\
\text { swallowing, } \\
\text { dysarthria, } \\
\text { lymphorrhea, and } \\
\text { airway } \\
\text { obstruction }\end{array}$ & $\begin{array}{l}\text { Sclerotherapy, } \\
\text { Chinese herb }\end{array}$ & $\begin{array}{l}18 \\
\text { (cessation } \\
\text { for surgery) }\end{array}$ & $6.0-11.8(7.6)$ & PR $(-28.1)$ & $\begin{array}{l}\text { Upper } \\
\text { respiratory } \\
\text { infection (3) }\end{array}$ \\
\hline 2 & $\begin{array}{l}2 \\
\text { weeks/F }\end{array}$ & Cystic LM & $\begin{array}{l}\text { Right neck, axilla, } \\
\text { trunk, and abdominal } \\
\text { cavity }\end{array}$ & $\begin{array}{l}\text { Anemia, } \\
\text { coagulation } \\
\text { disorder, and } \\
\text { bleeding }\end{array}$ & $\begin{array}{l}\text { Blood } \\
\text { transfusion }\end{array}$ & $\begin{array}{l}14 \\
\text { (cessation) }\end{array}$ & $3.5-11.1(6.2)$ & PR $(-27.9)$ & None \\
\hline 3 & $\begin{array}{l}3 \text { years/ } \\
\mathrm{F}\end{array}$ & Cystic LM & Left orbit & $\begin{array}{l}\text { Ocular } \\
\text { displacement }\end{array}$ & $\begin{array}{l}\text { Steroids and } \\
\text { propranolol }\end{array}$ & 6 & $5.4-11.0(8.3)$ & PR $(-24.3)$ & None \\
\hline 4 & $\begin{array}{l}10 \\
\text { months/ } \\
\mathrm{F}\end{array}$ & Cystic LM & Neck and mediastinal & $\begin{array}{l}\text { Airway } \\
\text { obstruction and } \\
\text { disturbance of } \\
\text { swallowing }\end{array}$ & $\begin{array}{l}\text { Sclerotherapy, } \\
\text { Chinese herb }\end{array}$ & 6 & $3.5-11.5(7.2)$ & PR (-23.4) & Cellulitis (3) \\
\hline 5 & $\begin{array}{l}11 \\
\text { years/M }\end{array}$ & Cystic LM & Neck and mediastinal & $\begin{array}{l}\text { Airway } \\
\text { obstruction and } \\
\text { disturbance of } \\
\text { swallowing }\end{array}$ & $\begin{array}{l}\text { Sclerotherapy, } \\
\text { Chinese herb }\end{array}$ & 6 & $1.8-5.9(3.9)$ & SD $(-15.0)$ & Stomatitis (1) \\
\hline 6 & $\begin{array}{l}8 \text { years/ } \\
\mathrm{M}\end{array}$ & KLA & $\begin{array}{l}\text { Bone, thoracic and } \\
\text { mediastinal }\end{array}$ & $\begin{array}{l}\text { Chylothorax and } \\
\text { coagulation } \\
\text { disorder }\end{array}$ & $\begin{array}{l}\text { Interferon and } \\
\text { propranolol }\end{array}$ & $\begin{array}{l}30 \\
\text { (cessation) }\end{array}$ & $4.4-9.0(7.5)$ & PR $(-55.4)$ & Pneumonia (3) \\
\hline 7 & $\begin{array}{l}8 \text { years/ } \\
\mathrm{M}\end{array}$ & KLA & $\begin{array}{l}\text { Bone, thoracic and } \\
\text { mediastinal }\end{array}$ & $\begin{array}{l}\text { Scoliosis, } \\
\text { chylothorax and } \\
\text { coagulation } \\
\text { disorder }\end{array}$ & $\begin{array}{l}\text { Steroids and } \\
\text { propranolol }\end{array}$ & 24 & $8.1-12.4(11.2)$ & $\mathrm{SD}(-8.3)$ & Stomatitis (1) \\
\hline 8 & $\begin{array}{l}20 \\
\text { years/M }\end{array}$ & $\mathrm{KLA}$ & $\begin{array}{l}\text { Bone, thoracic and } \\
\text { right chest wall }\end{array}$ & $\begin{array}{l}\text { Gastrointestinal } \\
\text { hemorrhage and } \\
\text { coagulation } \\
\text { disorder }\end{array}$ & Steroids & 12 & $4.7-6.0(5.5)$ & PR (-48.4) & Stomatitis (1) \\
\hline 9 & $\begin{array}{l}32 \\
\text { years/F }\end{array}$ & GLA & $\begin{array}{l}\text { Abdominal cavity } \\
\text { and skin }\end{array}$ & $\begin{array}{l}\text { Ascites, } \\
\text { coagulation } \\
\text { disorder, and } \\
\text { lymphorrhea }\end{array}$ & Chinese herb & 6 & $3.1-9.8(6.2)$ & PR $(-76.5)$ & None \\
\hline 10 & $\begin{array}{l}13 \\
\text { years/F }\end{array}$ & GLA & $\begin{array}{l}\text { Left upper limb, spleen } \\
\text { and skin }\end{array}$ & $\begin{array}{l}\text { Lymphorrhea, } \\
\text { bleeding and } \\
\text { cellulitis }\end{array}$ & $\begin{array}{l}\text { Surgery, Chinese } \\
\text { herb }\end{array}$ & 8 & $2.7-7.2(5.0)$ & $\operatorname{SD}(-0.1)$ & Stomatitis (1) \\
\hline 11 & $\begin{array}{l}35 \\
\text { years/F }\end{array}$ & GLA & $\begin{array}{l}\text { Abdominal cavity } \\
\text { and skin }\end{array}$ & $\begin{array}{l}\text { Lymphorrhea, } \\
\text { pain and cellulitis }\end{array}$ & $\begin{array}{l}\text { Surgery, Chinese } \\
\text { herb }\end{array}$ & 7 (cessation) & $8.3-13.8(11.0)$ & SD $(-1.0)$ & Stomatitis (1) \\
\hline 12 & $\begin{array}{l}20 \\
\text { years/F }\end{array}$ & GSD & Right thigh bone & $\begin{array}{l}\text { Pathological } \\
\text { fracture and pain }\end{array}$ & Surgery & $\begin{array}{l}18 \\
\text { (cessation) }\end{array}$ & $3.2-10.0(5.8)$ & $P R(-59.9)$ & Stomatitis (1) \\
\hline 13 & $\begin{array}{l}9 \text { years/ } \\
M\end{array}$ & GSD & Skull base & $\begin{array}{l}\text { Hearing loss and } \\
\text { spinal fluid } \\
\text { leakage }\end{array}$ & $\begin{array}{l}\text { Bisphosphonate, } \\
\text { interferon, and } \\
\text { propranolol }\end{array}$ & $\begin{array}{l}18 \\
\text { (cessation) }\end{array}$ & $3.6-6.2(5.7)$ & SD $(-19.1)$ & $\begin{array}{l}\text { Feeling of } \\
\text { fatigue (1) }\end{array}$ \\
\hline 14 & $\begin{array}{l}20 \\
\text { years/M }\end{array}$ & GSD & Right lower limbs & $\begin{array}{l}\text { Lymphorrhea and } \\
\text { spinal nerve palsy }\end{array}$ & $\begin{array}{l}\text { Bisphosphonate, } \\
\text { interferon, } \\
\text { epidural blood } \\
\text { patch therapy }\end{array}$ & 6 (cessation) & $3.0-10.9(6.9)$ & PR (-20.6) & Cellulitis (3) \\
\hline 15 & $\begin{array}{l}39 \\
\text { years/M }\end{array}$ & GSD & Paranasal sinus & $\begin{array}{l}\text { Facial nerve palsy, } \\
\text { pain, cerebral } \\
\text { infarction, skull } \\
\text { base } \\
\text { osteomyelitis, and }\end{array}$ & $\begin{array}{l}\text { Bisphosphonate } \\
\text { and radiotherapy }\end{array}$ & $\begin{array}{l}6 \text { (death } \\
\text { from } \\
\text { progression } \\
\text { of disease) }\end{array}$ & $3.5-7.4(6.7)$ & $\mathrm{SD}(-7.1)$ & Stomatitis (1) \\
\hline
\end{tabular}


Table 2 Characteristics of patients treated with sirolimus (Continued)

\begin{tabular}{|c|c|c|c|c|c|c|c|c|c|}
\hline $\bar{N}$ & $\begin{array}{l}\text { Age at } \\
\text { start/ } \\
\text { sex }\end{array}$ & Diagnosis & $\begin{array}{l}\text { Location of target } \\
\text { lesions }\end{array}$ & Complications & $\begin{array}{l}\text { Previous } \\
\text { treatment }\end{array}$ & $\begin{array}{l}\text { Dosing } \\
\text { period } \\
\text { (months) }\end{array}$ & $\begin{array}{l}\text { Range (mean) } \\
\text { of trough } \\
\text { concentrations } \\
(\mathrm{ng} / \mathrm{mL})\end{array}$ & $\begin{array}{l}\text { Evaluation } \\
\text { of } \\
\text { radiological } \\
\text { volumetric } \\
\text { change } \\
\text { (change } \\
\text { rate, \%) }\end{array}$ & $\begin{array}{l}\text { Adverse effects } \\
\text { associated with } \\
\text { sirolimus } \\
\text { (CTCAE Grade) }\end{array}$ \\
\hline & & & & $\begin{array}{l}\text { lateral medullary } \\
\text { syndrome }\end{array}$ & & & & & \\
\hline 16 & $\begin{array}{l}22 \\
\text { years/M }\end{array}$ & GSD & Right mandible & $\begin{array}{l}\text { Spinal fluid } \\
\text { leakage, pain, and } \\
\text { mal interdigitation }\end{array}$ & Surgery & 7 & $3.5-11.6(7.0)$ & PR $(-52.3)$ & None \\
\hline 17 & $\begin{array}{l}18 \\
\text { years/M }\end{array}$ & GSD & $\begin{array}{l}\text { Right thigh, lower } \\
\text { limbs }\end{array}$ & $\begin{array}{l}\text { Lymphorrhea and } \\
\text { pain }\end{array}$ & $\begin{array}{l}\text { Surgery, } \\
\text { Bisphosphonate, } \\
\text { interferon, } \\
\text { Chinese herb, } \\
\text { and propranolol }\end{array}$ & 14 & $3.2-5.1(4.2)$ & $\mathrm{SD}(-2.9)$ & Stomatitis (1) \\
\hline 18 & $\begin{array}{l}3 \text { years/ } \\
\mathrm{F}\end{array}$ & CCLA & $\begin{array}{l}\text { Thoracic and } \\
\text { mediastinal }\end{array}$ & $\begin{array}{l}\text { Appendicular } \\
\text { lymphedema, } \\
\text { respiratory } \\
\text { disorder, dyspnea, } \\
\text { and wheeze }\end{array}$ & $\begin{array}{l}\text { Steroids and } \\
\text { lymphatic } \\
\text { venous } \\
\text { anastomosis }\end{array}$ & 24 & $3.1-7.6(5.7)$ & $\mathrm{SD}(+2.3)$ & Pneumonia (2) \\
\hline 19 & $\begin{array}{l}3 \text { years/ } \\
\mathrm{F}\end{array}$ & CCLA & $\begin{array}{l}\text { Thoracic and } \\
\text { mediastinal }\end{array}$ & $\begin{array}{l}\text { Acute pancreatitis, } \\
\text { chylothorax, and } \\
\text { coagulation } \\
\text { disorder }\end{array}$ & $\begin{array}{l}\text { Steroids and } \\
\text { octreotide }\end{array}$ & 14 & $7.8-14.3(10.3)$ & $\mathrm{SD}(-0.1)$ & $\begin{array}{l}\text { Hyperlipidemia } \\
\text { (2) }\end{array}$ \\
\hline 20 & $\begin{array}{l}55 \\
\text { years/F }\end{array}$ & CCLA & $\begin{array}{l}\text { Abdominal cavity and } \\
\text { intestinal tract }\end{array}$ & $\begin{array}{l}\text { Anemia, intestinal } \\
\text { lymphangiectasia, } \\
\text { and protein losing } \\
\text { enteropathy }\end{array}$ & $\begin{array}{l}\text { Transfusion, } \\
\text { octreotide, } \\
\text { albumin, }\end{array}$ & $\begin{array}{l}6 \text { (death } \\
\text { from } \\
\text { progression } \\
\text { of disease) }\end{array}$ & $2.4-7.7(4.8)$ & $\mathrm{SD}(-2.0)$ & Stomatitis (1) \\
\hline
\end{tabular}

$M$ male, $F$ female, $L M$ lymphatic malformation, KLA kaposiform lymphangiomatosis, GLA generalized lymphatic anomaly, CCLA central conducting lymphatic anomaly, $P R$ partial response, $S D$ stable disease, CTCAE Common Terminology Criteria for Adverse Events

lesions $(n=6)$; - 1.0, cutaneous lesions $(n=12)$; 0.6667) (Additional file 1.

Among the 20 patients, 55.0\% (11/20) remain currently under treatment; however, 30.0\% (6/20) stopped treatment because their symptoms improved or did not improve (No. 11). Symptoms in one patient with GSD (No. 12) relapsed after discontinuation of sirolimus; sirolimus treatment was resumed in that case. Eighty percent of patients $(16 / 20)$ had side effects, such as stomatitis, infection, and hyperlipidemia. Grade 3 infections (upper respiratory infection, cellulitis, and pneumonia) associated with sirolimus were seen in three patients, but no patient discontinued treatment, and sirolimus was generally well tolerated.

\section{Discussion}

In this study, we analyzed the effects of sirolimus for the treatment of LMs. Our study protocol used novel and facile methods of radiological examination. We assessed the association between radiological response and clinical symptom improvements. Patients that had a reduction in the size of the lymphatic area affected showed an improvement in both clinical symptoms and QOL scores. Assessments of QOL and severity measurement scores were useful in evaluating the efficacy of sirolimus treatment.

Sirolimus has recently been reported to be effective in the treatment of vascular anomalies $[16,17]$. It has been shown to be highly efficacious in improving the condition of LM patients [17]. In a recent review, 95.2\% (60/ 63) of patients reported in previous studies showed some response to sirolimus treatment [17]. They included not only patients with LMs but also those with capillarylymphatico-venous malformations and venolymphatic malformations. In patients with LMs, the response rate was $92.1 \%$ (35/38, excluding seven patients who were not reported), with three patients having PD. Although we have to consider publication bias, the response rate in this review was extremely high. Their review included a heterogeneous patient population that was similar to the patients in our study. If our response criteria included not only the radiological response but also severity and QOL scores, then the response rate would increase to $70 \%(14 / 20)$, hence exceeding the radiological response rate alone. These results were also similar to those of previous reports. Most patients had a partial response, not a complete response [17], but sirolimus may be a very useful option for the treatment of patients with LMs. For example, the ability of sirolimus to 

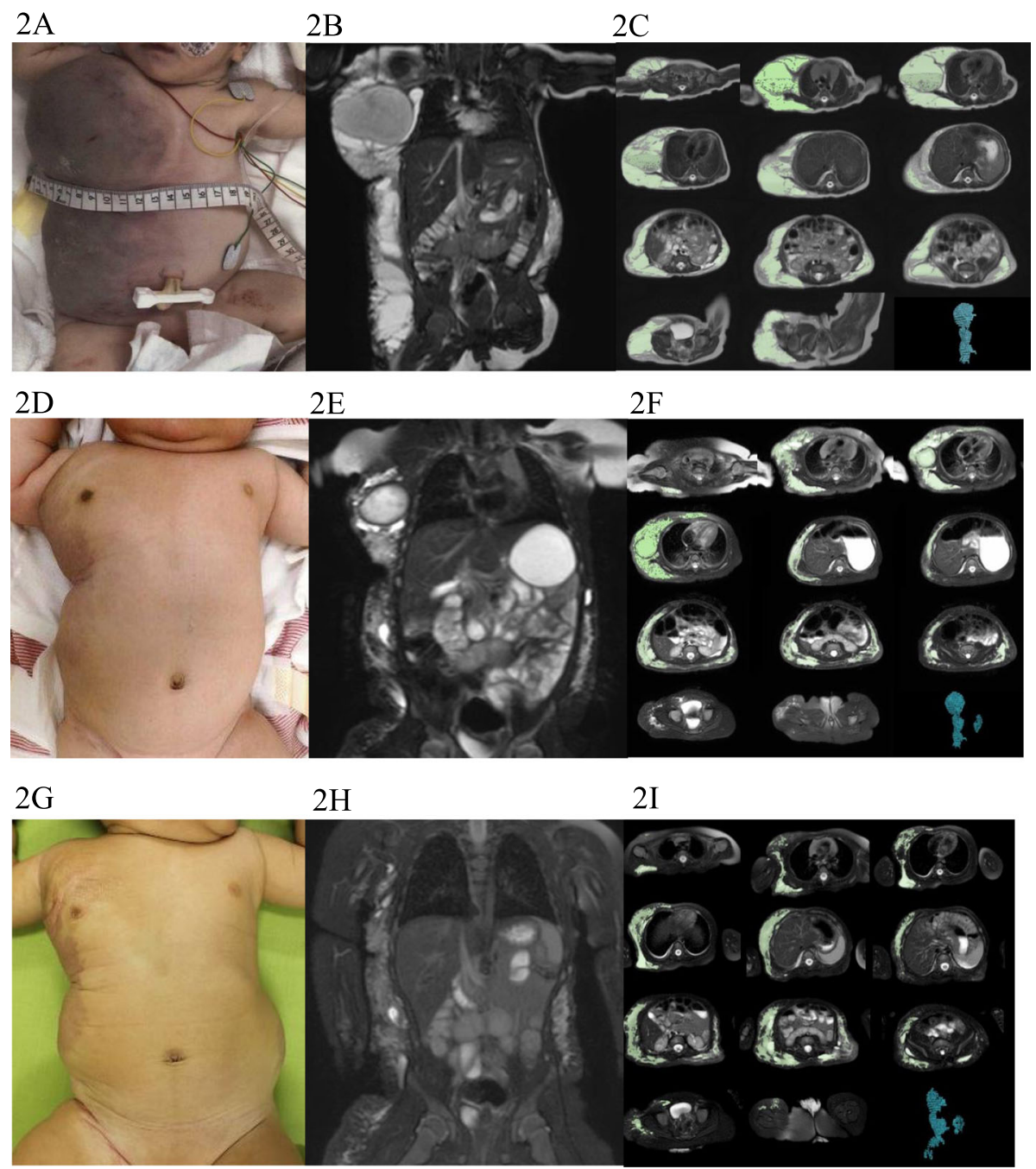

Fig. 2 Clinical photograph, MRI, and volumetric measurements for case number 2. A 2-week-old girl had a giant cystic LM lesion in her right neck, axilla, trunk, and abdominal cavity. a-c Pretreatment. $\mathbf{d}$-f 3 months after administration of sirolimus. $\mathbf{g}$-i 6 months after administration of sirolimus. $\mathbf{c}, \mathbf{f}$, and $\mathbf{i}$ show volumetric measurements evaluated using the Digital Imaging and Communications in Medicine (DICOM) viewer (OsiriX)

shrink LM lesions may make surgical resection possible in more patients, and sirolimus could play a role in the preoperative treatment for refractory cases of massive LM lesions.

Methods for evaluating the efficacy of sirolimus treatment have not been established. Because LM patients have variable symptoms and problems, we need to establish objective and comprehensive methods. A previous phase II trial reported using three distinct assessments involving radiological examination, functional impairment score, and QOL score [6]. Scoring functional impairment has never been validated for quantification of LAs. Our primary endpoint was radiological volumetric change at 6 months because this parameter is the most objective one amongst various other parameters. We evaluated not only the clinical symptoms but also severity and QOL scores.
We referenced common criteria of each organ and dysfunctions because these criteria were very useful and easy for us to assess $[14,15]$. Our results revealed that severity scores could be used to assess treatment efficacy, but we used only the sum score and not each individual symptom score in the statistical analysis because of differences in symptoms experienced by each patient. We also analyzed the change in score for each organ in our patients (see Additional file 1), which showed a tendency for improvement in each organ. Unfortunately, these data were insufficient to examine the efficacy because the number of cases was small. However, each score might be able to be used in evaluating the severity of each symptom because these scores have already been used as criteria for assessing each organ in various studies. Furthermore, we used QOL scores and these were very useful in evaluating 

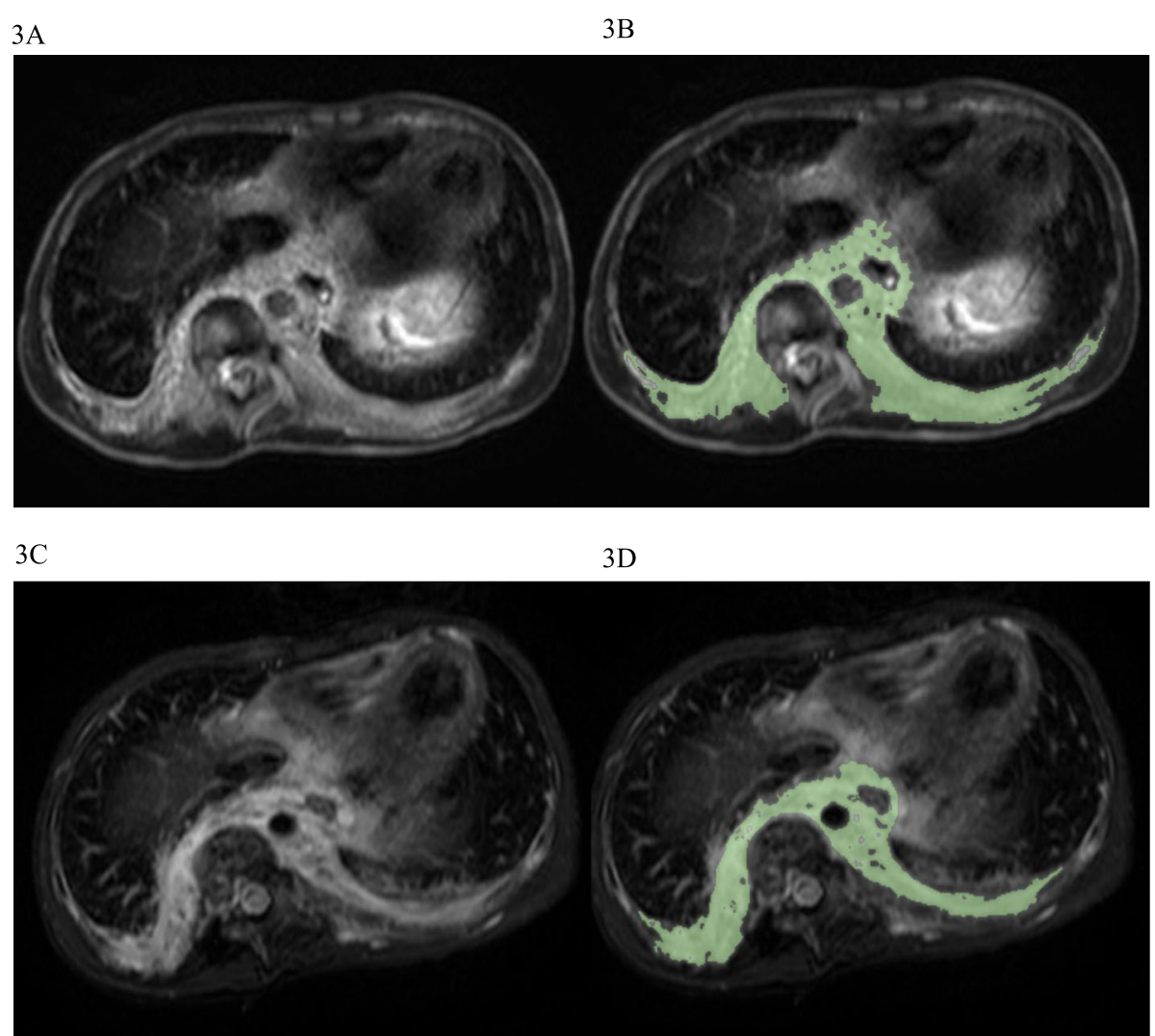

Fig. $3 \mathrm{MRl}$ and volumetric measurements for case number 7. An 8-year-old boy with KLA suffered from severe scoliosis, pain, thrombocytopenia, and coagulopathy. T2-weighted MRI of the chest demonstrates diffuse thickening of the interlobular septa and retroperitoneal soft tissue mass, which is the target lesion. $\mathbf{a}$ and $\mathbf{b}$ Pretreatment. $\mathbf{c}$ and $\mathbf{d} 6$ months after administration of sirolimus. $\mathbf{b}$ and $\mathbf{d}$ show the volumetric measurements evaluated using the Digital Imaging and Communications in Medicine (DICOM) viewer (OsiriX)

patients. It is difficult to do QOL surveys of pediatric patients because we must consider the development and age of the child as well as the specific disease. PedsQL Scales were used in a previous study [6] and have been shown to have high versatility in a variety of diseases and situations. It has been found that there is a significant relationship between observed radiological reduction in lesions and improvement in PedsQL scores. Our results showed that volume reduction in lesions could lead to improvements in a patient's state.

Precise assessment of radiological images of LAs is very important. No standardized methods for evaluating

Table 3 Severity and QOL scores during sirolimus treatment

\begin{tabular}{|c|c|c|c|c|c|c|c|c|c|c|c|c|}
\hline & \multirow{2}{*}{\multicolumn{3}{|c|}{ Severity score }} & \multicolumn{9}{|l|}{ QOL score } \\
\hline & & & & \multicolumn{3}{|l|}{ All score } & \multicolumn{3}{|l|}{ Physical score } & \multicolumn{3}{|c|}{ Psychological score } \\
\hline & Pretreatment & $\begin{array}{l}6 \\
\text { months }\end{array}$ & $\begin{array}{l}p \\
\text { value }^{a}\end{array}$ & Pretreatment & $\begin{array}{l}6 \\
\text { months }\end{array}$ & $\begin{array}{l}p \\
\text { value }^{a}\end{array}$ & Pretreatment & $\begin{array}{l}6 \\
\text { months }\end{array}$ & $\begin{array}{l}p \\
\text { value }^{a}\end{array}$ & Pretreatment & 6 months & $\begin{array}{l}p \\
\text { value }^{a}\end{array}$ \\
\hline $\begin{array}{l}\text { All patients } \\
(n=20)\end{array}$ & $8.0(3-20)$ & $\begin{array}{l}5.0(1- \\
20)\end{array}$ & 0.0029 & $58.1(17.4-94.6)$ & $\begin{array}{l}77.3 \\
(7.7- \\
91.3)\end{array}$ & 0.0129 & $50.0(0-100)$ & $\begin{array}{l}77.6(0- \\
100)\end{array}$ & 0.0105 & $\begin{array}{l}65.0(12.5- \\
100)\end{array}$ & $\begin{array}{l}75.8(16.7- \\
100)\end{array}$ & 0.0052 \\
\hline $\begin{array}{l}\text { PR patients } \\
(n=10)\end{array}$ & $8.0(3-13)$ & $\begin{array}{l}4.5(1- \\
7)\end{array}$ & 0.0020 & $58.1(17.4-84.7)$ & $\begin{array}{l}76.2 \\
(51.1- \\
91.3)\end{array}$ & 0.0117 & $\begin{array}{l}48.4(18.8- \\
98.4)\end{array}$ & $\begin{array}{l}77.6 \\
(21.9- \\
98.4)\end{array}$ & 0.0078 & $\begin{array}{l}65.0(12.5- \\
78.1)\end{array}$ & $\begin{array}{l}75.8(60- \\
90.5)\end{array}$ & 0.0156 \\
\hline $\begin{array}{l}\text { SD patients } \\
(n=10)\end{array}$ & $6.5(3-20)$ & $\begin{array}{l}5.5(1- \\
20)\end{array}$ & 0.4375 & $63.3(23.9-94.6)$ & $\begin{array}{l}79.8 \\
(7.7- \\
91.3)\end{array}$ & 0.3828 & $53.1(0-100)$ & $\begin{array}{l}69.5(0- \\
100)\end{array}$ & 0.367 & $\begin{array}{l}67.5(27.5-- \\
100)\end{array}$ & $\begin{array}{l}82.5 \\
(16.7-100)\end{array}$ & 0.2188 \\
\hline
\end{tabular}

Values presented as median (range)

$P R$ partial response, $S D$ stable disease

${ }^{a}$ Wilcoxon signed rank test for comparison between pretreatment and 6 months 
LAs have been reported. We used MRI to assess volumetric changes in lesions because MRI can be used to assess soft tissues with high resolution and without radiation exposure and is often used to evaluate vascular anomalies. The DICOM viewer OsiriX is an easy-to-use open-source software that allows measurement of the area of a lesion with the ROI tool. Lymphatic lesions, including lymphedema and lymphatic cysts as well as lymphatic fluids, are detectable on T2 fat-saturated images as high-intensity areas. Using this methodology, we could readily evaluate our patients' images. Thus, in this study, we used simple and novel methods for evaluating LMs.

LAs result from defects in the lymphangiogenesis, lymphatic development, and lymphatic vasculature remodeling [18]. Recent studies revealed that there were somatic genetic abnormalities in patients with LMs [7]. Sporadic LMs may be caused by somatic changes in components of the phosphoinositide 3-kinase (PI3K)/ mTOR and RAS/mitogen-activated protein (MAPK) signaling pathways [19]. MTOR inhibitors target protein synthesis downstream of the Akt pathway and are predicted to be effective in disorders where the mTOR growth control pathway is affected [19]. Somatic activation of related genes can cause the growth of abnormal lymphatic endothelial cells and dysplasia of lymphatic canals and valves [18]. This would be associated with the pathogenesis of local lymphatic dysfunction or excessive activation of local lymphatic tissues. It may occur at the normal distribution areas or from lesions that are not distributed. Although the mechanism by which sirolimus affects LMs is still unknown at present, normalization or inactivation of signaling pathways involved in the development of abnormal lesions might play a role in the efficacy of sirolimus treatment. In experimental models, sirolimus is thought to act on lymphatic tissues within lesions to regulate the production and leakage of lymph by decreasing lymphatic endothelial cell activity. In a lymphangiectasia mouse model, Baluk et al. demonstrated that sirolimus not only prevents the growth of abnormal lymphatics but also induces the partial regression of lesions, without apparent effects on normal lymphatics [20]. This regression is accompanied by reductions in Prox1 and vascular endothelial growth factor receptor-3 but not by caspase-dependent apoptosis of lymphatic endothelial cells. In our study, sirolimus caused a reduction in the volume of lymphatic lesions. This may lead to an impairment in abnormal lymphatic flow and a decreased flow of lymph fluid. However, the dilated lymphatic wall remained.

Our study had some limitations. First, this was a study and the number of registered patients was small. It included patients with a variety of LAs and heterogeneous disorders, so it was necessary to consider the differences of each disease or condition. Second, the severity scores that we used have not been validated in assessing vascular anomalies; however, these severity scores consist of general criteria for evaluating severities of each organ and condition, and we will be assessing their validity for these conditions in a future study. Third, trough levels should be maintained at $5-15 \mathrm{ng} / \mathrm{ml}$, as shown in previous studies; however, actual trough levels ranged more widely. In a previous phase 2 study, trough levels were maintained at $10-15 \mathrm{ng} / \mathrm{ml}$ [6]. A systematic review reported that the expected trough levels of sirolimus in most studies $(19 / 25,76.0 \%)$ were $5-15 \mathrm{ng} / \mathrm{ml}$ [21]. Currently, there are no standardized methods for its optimal dosing. A previous in vitro study demonstrated that the highest dose of rapamycin reduced the incidence of lymphatic anomalies, but it also increased toxicities [20]. There were some patients who achieved good responses with trough levels less than $5 \mathrm{ng} / \mathrm{ml}$. Further study of the association between trough levels and efficacy and safety of sirolimus is needed.

In conclusion, we performed a prospective study of sirolimus treatment in patients with LMs and employed useful assessment methods. Sirolimus reduces the lymphatic tissue volume associated with LMs and could lead to improvement of clinical symptoms and QOL.

\section{Additional file}

Additional file 1: Changes in severity score after sirolimus treatment. (DOCX $33 \mathrm{~kb})$

\section{Abbreviations}

BSA: Body surface area; CCLA: Central conducting lymphatic anomaly; CR: Complete response; CTCAE: Common Terminology Criteria for Adverse Events; DICOM: Digital Imaging and Communications in Medicine; FACTG: Functional Assessment of Cancer Therapy-General; GLA: Generalized lymphatic anomaly; GSD: Gorham-Stout disease; ISSVA: International Society for the Study of Vascular Anomalies; KLA: Kaposiform lymphangiomatosis; LA: Lymphatic anomaly; LM: Lymphatic malformation; MRI: Magnetic resonance imaging; mTOR: mammalian target of rapamycin; PD: Progressive disease; PR: Partial response; QOL: Quality of life; ROI: Region of interest; SD: Stable disease

\section{Acknowledgements}

We thank Dr. Yoriko Matsuzawa, Dr. Tomohiro Hori, Dr. Kaori Kanda, Dr. Takeshi Kimura, Dr. Kazuo Kubota, and Dr. Norio Kawamoto of Gifu University for their helpful comments. We thank Dr. Akihiro Fujino, Dr. Mikiko Miyasaka, and Dr. Shunsuke Nosaka from the National Center for Child Health and Development for their helpful comments. We thank Mark Abramovitz, PhD, from Edanz Group (www.edanzediting.com/ac) for editing a draft of this manuscript.

\section{Authors' contributions}

$\mathrm{MO}, \mathrm{RA}, \mathrm{HH}$, and $\mathrm{FT}$ conceived the study and participated in its design. $\mathrm{MO}$ and RA performed progress management and adjustment of the overall clinical trial. MO, AN, SY, and SE provided medical care for patients and collected data. $\mathrm{HH}$ was responsible for the statistical analysis of this clinical trial. MO, AN, SY, and SE evaluated efficacy and safety in this study. MO wrote the manuscript. TF supervised management of the patients. All authors read and approved the final manuscript. 


\section{Funding}

The present study was supported in part by a Clinical research-clinical trial promotion research project (18lk0201055h0003) and Practical Research Project for Rare/Intractable Diseases(18ek0109277h0002) from Japan's Agency for Medical Research and Development, AMED.

\section{Availability of data and materials}

The datasets and analysis performed during the current study are available from the corresponding author upon reasonable request.

\section{Ethics approval and consent to participate}

This study received approval from the Institutional Review Board at Gifu University Hospital, Gifu, Japan. Each patient or patient's parent signed an informed consent after receiving a summary explaining study procedures. The trial was also registered in the UMIN Clinical Trials Registry (UMIN000016580).

\section{Consent for publication}

Each patient or patient's parent signed a consent for publication.

\section{Competing interests}

M.O. and T.F. received research funding from Nobelpharma. Sirolimus tablets were supplied by Nobelpharma. The other authors declare no competing interests.

\section{Author details}

'Department of Pediatrics, Graduate School of Medicine, Gifu University, 1-1, Yanagido, Gifu 501-1194, Japan. ${ }^{2}$ Innovative and Clinical Research Promotion Center, Graduate School of Medicine, Gifu University, 1-1, Yanagido, Gifu 501-1194, Japan. ${ }^{3}$ Clinical Research Center, National Hospital Organization Nagoya Medical Center, 4-1-1, Sannomaru, Naka-ku, Nagoya, Aichi 460-0001, Japan.

Received: 4 December 2018 Accepted: 4 June 2019

Published online: 13 June 2019

\section{References}

1. Trenor CC 3rd, Chaudry G. Complex lymphatic anomalies. Semin Pediatr Surg. 2014;23:186-90.

2. International Society for the Study of Vascular Anomalies: ISSVA classification for Vascular Anomalies (approved at the May 2018 General Assembly in Amsterdam, the Netherlands) http://issva.org/classification (Accessed June 2018).

3. Foley LS, Kulungowski AM. Vascular anomalies in pediatrics. Adv Pediatr Infect Dis. 2015;62:227-55.

4. Ozeki M, Fujino A, Matsuoka K, Nosaka S, Kuroda T, Fukao T. Clinical features and prognosis of generalized lymphatic anomaly, Kaposiform lymphangiomatosis and Gorham-stout disease. Pediatr Blood Cancer. 2016; 63:832-8.

5. Hammill AM, Wentzel M, Gupta A, et al. Sirolimus for the treatment of complicated vascular anomalies in children. Pediatr Blood Cancer. 2011;57: 1018-24.

6. Adams DM, Trenor CC 3rd, Hammill AM, et al. Efficacy and safety of sirolimus in the treatment of complicated vascular anomalies. Pediatrics. 2016;2:e20153257.

7. Boscolo E, Coma S, Luks VL, et al. AKT hyper-phosphorylation associated with PI3K mutations in lymphatic endothelial cells from a patient with lymphatic malformation. Angiogenesis. 2015;18:151-62.

8. Flores MV, Hall CJ, Crosier KE, Crosier PS. Visualization of embryonic lymphangiogenesis advances the use of the zebrafish model for research in cancer and lymphatic pathologies. Dev Dyn. 2010;239:2128-35.

9. Huber S, Bruns CJ, Schmid G, et al. Inhibition of the mammalian target of rapamycin impedes lymphangiogenesis. Kidney Int. 2007;71:771-7.

10. Kobayashi S, Kishimoto T, Kamata S, Otsuka M, Miyazaki M, Ishikura H. Rapamycin, a specific inhibitor of the mammalian target of rapamycin, suppresses lymphangiogenesis and lymphatic metastasis. Cancer Sci. 2007; 98:726-33.

11. Luo Y, Liu L, Rogers D, et al. Rapamycin inhibits lymphatic endothelial cell tube formation by downregulating vascular endothelial growth factor receptor 3 protein expression. Neoplasia. 2012;14:228-37.
12. Varni JW, Seid M, Kurtin P. PedsQL ${ }^{\mathrm{TM}}$ 4.0: reliability and validity of the pediatric quality of life inventory ${ }^{\mathrm{TM}}$ version 4.0 generic Core scales in healthy and patient populations. Med Care. 2001;39:800-12.

13. Fairclough DL, Cella DF. Functional assessment of Cancer therapy (FACT-G): non-response to individual questions. Qual Life Res. 1996;5:321-9.

14. Fogarty PF, Tarantino MD, Brainsky A, Signorovitch J, Grotzinger KM. Selective validation of the $\mathrm{WHO}$ bleeding scale in patients with chronic immune thrombocytopenia. Curr Med Res Opin. 2012;28:79-87.

15. van Swieten JC, Koudstaal PJ, Visser MC, Schouten HJ, van Gijn J. Interobserver agreement for the assessment of handicap in stroke patients. Stroke. 1988;19:604-7.

16. Lackner H, Karastaneva A, Schwinger W, et al. Sirolimus for the treatment of children with various complicated vascular anomalies. Eur J Pediatr. 2015; 174:1579-84.

17. Wiegand S, Wichmann G, Dietz A. Treatment of lymphatic malformations with the mTOR inhibitor Sirolimus: a systematic review. Lymphat Res Biol. 2018;16:330-9.

18. Brouillard P, Boon L, Vikkula M. Genetics of lymphatic anomalies. J Clin Invest. 2014;124:898-904.

19. Queisser A, Boon LM, Vikkula M. Etiology and genetics of congenital vascular lesions. Otolaryngol Clin N Am. 2018;51:41-53.

20. Baluk P, Yao LC, Flores JC, Choi D, Hong YK, McDonald DM. Rapamycin reversal of VEGF-C-driven lymphatic anomalies in the respiratory tract. JCI Insight. 2017;2:e90103.

21. Nadal M, Giraudeau B, Tavernier E, et al. Efficacy and safety of mammalian target of rapamycin inhibitors in vascular anomalies: a systematic review. Acta Derm Venereol. 2016;96:448-52.

\section{Publisher's Note}

Springer Nature remains neutral with regard to jurisdictional claims in published maps and institutional affiliations.
Ready to submit your research? Choose BMC and benefit from:

- fast, convenient online submission

- thorough peer review by experienced researchers in your field

- rapid publication on acceptance

- support for research data, including large and complex data types

- gold Open Access which fosters wider collaboration and increased citations

- maximum visibility for your research: over $100 \mathrm{M}$ website views per year

At $\mathrm{BMC}$, research is always in progress.

Learn more biomedcentral.com/submissions 